\title{
Seroprevalence of Toxoplasma gondii among HIV Patients in Jahrom, Southern Iran
}

\author{
Hassan Rezanezhad', Fateme Sayadi², Enayatollah Shadmand³, Seyed Dawood Mousavi Nasab ${ }^{3}$, \\ Hadi Rezaei Yazdi³, Kavous Solhjoo', Akbar Kazemi ${ }^{3}$, Monireh Maleki ${ }^{4}$, Abbas Ahmadi Vasmehjani ${ }^{3, *}$ \\ 'Zoonoses Research Center, ${ }^{2}$ Department of Student Research Committee, ${ }^{3}$ Department of Microbiology, School of Medicine, Jahrom University of \\ Medical Sciences, Jahrom, Iran; ' ${ }^{4}$ epartment of Clinical Biochemistry, School of Medicine, Tehran University of Medical Sciences, Tehran, Iran
}

\begin{abstract}
Toxoplasma gondii is an important opportunistic agent especially in immunocompromised hosts and can cause significant morbidity and mortality. Hence, detection and monitoring of anti-Toxoplasma antibodies are of a great interest in HIV-infected patients. A study on the prevalence of toxoplasmosis and associated risk factors was carried out among HIV-infected patients in Jahrom, southern Iran. The prevalence of anti-Toxoplasma IgG antibodies was $21.1 \%$ in HIV-infected patients by ELISA. PCR was performed on all of the samples, and 1 of the blood samples was positively detected. Among the HIV patients, anti-Toxoplasma IgG antibodies were significantly higher in age group of 30-39 years old $(P=0.05)$. The seroprevalence of toxoplasmosis in patients with $\mathrm{CD} 4^{+}<100$ cells $/ \mu \mathrm{l}$ was $33.3 \%$ that was significantly higher than the other groups $(P=0.042)$ with or without lgG antibodies. The $\mathrm{CD} 4^{+}$count mean of seropositive patients was lower than that of seronegative patients. The seroprevalence of toxoplasmosis in patients with highly active antiretroviral therapy was significantly less than patients without therapy $(P=0.02)$. In conclusion, this study showed low seroprevalence of latent toxoplasmosis among HIV-infected patients in the region and confirmed the need for intensifying prevention efforts among this high-risk population and also the risk of toxoplasmosis reactivation which could be important among this population.
\end{abstract}

Key words: Toxoplasma gondii, HIV patient, seroprevalence, PCR, IgG, Jahrom, Iran

Toxoplasma gondii infection has been indicated to be a common opportunistic infection which can lead to a life-threatening disease, especially among patients infected with human immunodeficiency virus (HIV). Most T. gondii infections in humans are asymptomatic; however, they are the most common severe neurologic infections among patients with acquired immunodeficiency syndrome (AIDS), and they also can cause severe toxoplasmic encephalitis (TE) via acute infection or reactivation of latent infections. Over the past 2 decades in developing countries, $T$. gondii gradually shows as a life-threatening condition among AIDS patients [1-3].

The prevalence of $T$. gondii infection varies depending on geographical areas and population groups. Generally, the seroprevalence in Iran is 39\% [4]. Low seropositivity has been observed in North America and Northern Europe [5], and high seroprevalences (75-85\%) have been reported in Latin Ameri-

\footnotetext{
- Received 10 July 2016, revised 26 September 2016, accepted 4 October 2016.

*Corresponding author (ahvasmehjani @gmail.com)

(c) 2017, Korean Society for Parasitology and Tropical Medicine

This is an Open Access article distributed under the terms of the Creative Commons Attribution Non-Commercial License (http://creativecommons.org/licenses/by-nc/4.0) which permits unrestricted non-commercial use, distribution, and reproduction in any medium, provided the original work is properly cited.
}

ca, Central and Eastern Europe, and Southeast Asia [6,7]. Studies around the world reported that T. gondii infection in HIVinfected patients varied by geographical locations with prevalences between $8.0-97.0 \%$ [8]. Also, it is important that serological studies in many groups have shown that about $20 \%$ of people would have acquired the infection by the age of 20 years, and up to $50 \%$ by the age of 50 years [9].

Because of the risk of damage in the CNS and high morbidity in HIV-positive individuals, it is important to determine the prevalence of T. gondii infection in HIV patients. Consequently, in recent years, detection and monitoring of anti-Toxoplasma antibodies have become a great concern in HIV-infected patients. The purpose of this study was to determine the prevalence of T. gondii infection among HIV patients, and to identify possible risk factors associated with toxoplasmosis in Jahrom County, Iran.

This study was carried out on 90 HIV-infected patients in a southern part of Iran (Jahrom and Yazd) between September 2013 and October 2014. Written informed consent forms, compiled by the Ethics Committee of Jahrom University of Medical Sciences, Iran were signed by the patients. The participants were recruited to the Infectious Disease Department, 
which represents the most important center for diagnosis and monitoring of HIV-infected patients in this region. The diagnosis of HIV status was based on at least 1 previous and documented HIV positive ELISA confirmed by a western-blot test. Demographic information, such as the age, gender, socio-economic (living area, monthly income, and education level) and clinical data (contamination mode, disease duration, and antiretroviral therapy), were collected from patients during their visits to the Department. Two blood samples were collected from each patient; the first one in a plastic serum tube and the second one in an EDTA tube. The EDTA whole blood was tested on the same day for $\mathrm{CD}^{+}{ }^{+} \mathrm{T}$ cell counts in the laboratory of University Hospital of Jahrom, southern Iran. The serum samples were labeled and stored at $-20^{\circ} \mathrm{C}$, then transported to the reference laboratory in Jahrom.

Specific anti-T. gondii IgG antibodies were analyzed using ELISA by Toxo-IgG kit (Dia Pro Diagnostic Bioprobes, Srl, Italy) with the sensitivity of $97.2 \%$ and the specificity of $93.8 \%$. A patient sample with cut-off value (antibody titer) higher or equal to $50 \mathrm{IU} / \mathrm{ml}$ was considered positive. That means that they had a prior contact with T. gondii. The IgG titers lower than $50 \mathrm{IU} / \mathrm{ml}$ were regarded negative. The negative results were indicative of absence of acquired immunity, but we did not exclude a recent infection. The $\mathrm{CD}^{+} \mathrm{T}$ cell counts for each participant had been done by flow cytometry (Partec, Germany).

DNA was extracted from whole blood samples, using DNA extraction kit by DNPTM Kit (CinnaGen, Iran) according to the manufacture's protocol. The DNA extracted from whole blood samples was kept at $-80^{\circ} \mathrm{C}$ until PCR was performed. The PCR reaction was performed using specific-primers for B1 Gene and the protocol as described previously [10]. The first rounds of TTV nested PCR reactions contained $5 \mu \mathrm{l}$ of template DNA, $1 \mu \mathrm{l}$ (10 pM stock) of each amplification B1-oligonucleotide primers 5 '-GGAACTGCATCCGTTCATGAG-3' and 5'-TCTTTAAAGCGTTCGTGGTC-3', respectively, $0.5 \mu \mathrm{l}$ of dNTP (10 mM stock), $2.5 \mu \mathrm{l}$ of Taq DNA polymerase (Fermentas GmbH, St. Leon-Rot, Germany), $0.5 \mathrm{mM}$ of $\mathrm{MgCl}_{2}$, and $2.5 \mu \mathrm{l}$

Table 1. Anti-Toxoplasma gondii lgG antibody titers among HIVinfected patients in Jahrom, Iran

\begin{tabular}{lcc}
\hline IgG titer (IU/ml) & No. patients (\%) & $\begin{array}{c}\text { CD4 } 4^{+} \text {T-cells } \\
\text { mean } \pm \text { SD (cells/ } \mu l)\end{array}$ \\
\hline$>1,000$ & $11(57.9)$ & $211.5 \pm 1.4$ \\
$100-1,000$ & $3(15.8)$ & $274.0 \pm 12.1$ \\
$50-100$ & $5(26.3)$ & $321.0 \pm 17.3$ \\
\hline
\end{tabular}

of $10 \times$ buffer $(500 \mathrm{mM}$ of $\mathrm{KCl}$ and Tris- $\mathrm{HCl}, \mathrm{pH}=8.4)$. PCR amplifications were performed as follows: Reactions were cycled 40 times with denaturation at $93^{\circ} \mathrm{C}$ for $5 \mathrm{~min}$ followed by annealing at $57^{\circ} \mathrm{C}$ for $10 \mathrm{sec}$ and finally extension at $72^{\circ} \mathrm{C}$ for $30 \mathrm{sec}$ with a further final $7 \mathrm{~min}$ extension at $72^{\circ} \mathrm{C}$. The program used for the second PCR round was designed; nested PCR reactions contained $1 \mu \mathrm{l}$ first-round product, $10 \mathrm{mM}$ Tris$\mathrm{HCl}, \mathrm{pH} 8.3$ (at 25 $5^{\circ}$ ), $50 \mathrm{mM} \mathrm{KCl}, 3 \mathrm{mM} \mathrm{MgCl} 2,0.5 \mu \mathrm{M}$ each nested primers $5^{\prime}$-TGCATAGGTTGCAGTCACTG-3' and 5'-GGCGACCAATCTGCGAATACACC-3', 0.1 mM each dNTP, and $1 \mathrm{U}$ Taq DNA polymerase. Nested PCRs were cycled 40 times using a denaturation step of $93^{\circ} \mathrm{C}$ for $10 \mathrm{sec}$, followed by annealing at $62.5^{\circ} \mathrm{C}$ for $10 \mathrm{sec}$, and extension at $72^{\circ} \mathrm{C}$ for 15 sec. The amplification products of the second PCR round were 93 bp.

All analyses used SPSS for windows version 16.0 (SPSS, Chicago, Illinois, USA). All measurements are expressed as the mean \pm SEM. Possible association was identified using the Chisquare or Fishers' exact test. $P$-values less than 0.05 were regarded as statistically significant.

Socio-economic and clinical data are shown in Table 1. The mean age of HIV-infected patients was $41.0 \pm 12.1$ years, range from 20 to 58 years. The mean $\mathrm{CD}^{+} \mathrm{T}$ cells count was $312.2 \pm$

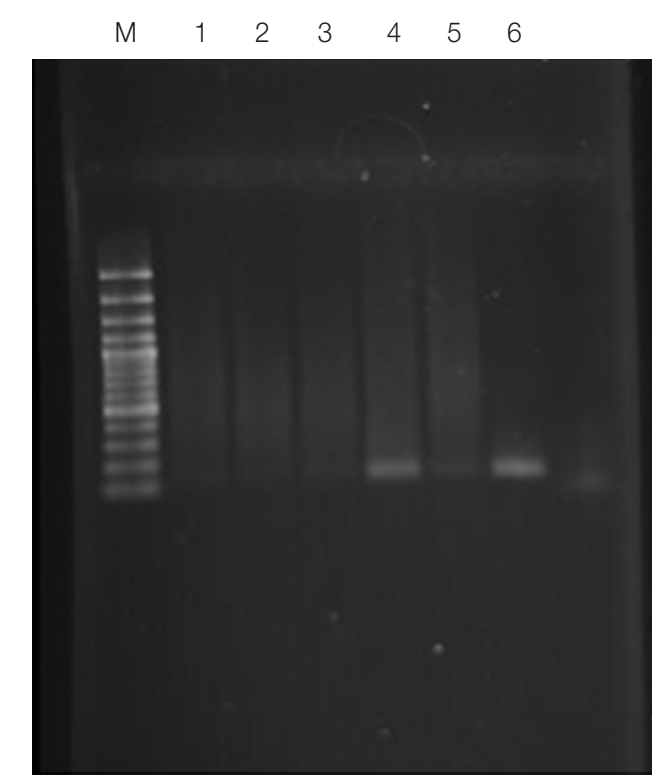

Fig. 1. PCR amplification products of Toxoplasma gondii B1 gene among HIV patient's serum sample. Lane M, molecular weight marker (GeneRulerTM 100 bp Plus DNA Ladder, Fermentas UAB, Vilnius, Lithuania); 1-3, negative samples, 4, positive sample; 5, negative control $\left(\mathrm{H}_{2} \mathrm{O}\right.$ instead of DNA); 6, positive control (DNA of Toxoplasma tachyzoites). 
134.1 cells/ $/$ l. The duration of HIV-infected patients ranged from 6-39 months with a mean of 36.3 months.

Overall, out of the total 90 HIV positive participants included in this study, 19 (21.1\%) were anti-T. gondii IgG antibody seropositive. The detection of T. gondii DNA using PCR of blood samples revealed that only 1 sample $(1.1 \%)$ was positive, and this sample had the highest titer $(2,540 \mathrm{IU} / \mathrm{ml})$ in IgG-ELISA (Fig. 1). The IgG titer was greater than $1,000 \mathrm{IU} / \mathrm{ml}$ in $57.9 \%$ cases. Different categories of IgG anti-T. gondii titer are summarized in Table 1.

Several sociodemographic and other factors predisposing to T. gondii infection were also assessed (Table 2). $\mathrm{CD}^{+} \mathrm{T}$ cell counts were available for 90 of the study participants, and were categorized into 3 groups: $\mathrm{CD} 4^{+}<100, \mathrm{CD}^{+} 100-500$, and $\mathrm{CD} 4^{+}>500$. The $\mathrm{CD} 4^{+}$count mean of patients with positive and negative Toxoplasma serology was $271.5 \pm 14.4$ cells $/ \mu$ land $353.5 \pm 28.2$ cells/ $\mu \mathrm{l}$, respectively. The seroprevalence of toxo- plasmosis in patients with $\mathrm{CD}_{4}^{+}<100$ was $33.3 \%$ that was significantly higher than the other groups $(P=0.042)$. The rate of Toxoplasma infection was significantly higher among patients without therapy than underlying therapy (51.6\% vs $5.1 \%$; $P=0.02$ ). The patients' ages were divided into 4 groups (Table 2). The seroprevalence of toxoplasmosis was different between age groups. More than a half (52.6\%) of seropositive T. gondii cases were within the age group 30-39 years $(P=0.05)$.

T. gondii infection was not significantly associated $(P=0.5)$ with gender of the study participants. Similarly, no significant differences in $T$. gondii infection with the place of residence, educational levels, marital status, and neurological symptoms were observed (Table 2).

In the present study, the seroprevalence of anti-T. gondii IgG antibodies among the HIV positive study participants was $21.1 \%$. Our results were close to some previous reports, for instance, toxoplasmosis in HIV/AIDS patients in Shiraz [11] and

Table 2. Factors associated with the prevalence of toxoplasmosis among HIV patients in Jahrom, southern Iran

\begin{tabular}{|c|c|c|c|c|}
\hline Characteristics & Toxoplasma positive no. (\%) & Toxoplasma negative no. (\%) & Total no. (\%) & $P$-value \\
\hline Gender & & & & 0.5 \\
\hline Male & $13(21.3)$ & $48(78.7)$ & $61(67.8)$ & \\
\hline Age groups (year) & & & & 0.05 \\
\hline $20-29$ & $5(26.3)$ & $19(79.2)$ & $24(23.3)$ & \\
\hline $30-39$ & $10(19.2)$ & $42(71.8)$ & $52(57.8)$ & \\
\hline $40-49$ & $1(10.0)$ & $9(90.0)$ & $10(11.1)$ & \\
\hline$\geq 50$ & $3(75.0)$ & $1(25.0)$ & $4(4.4)$ & \\
\hline Living area (residence) & & & & 0.64 \\
\hline Urban & $17(28.4)$ & $63(71.6)$ & $80(88.9)$ & \\
\hline Rural & $2(20.0)$ & $8(80.0)$ & $10(11.1)$ & \\
\hline Education level & & & & 0.57 \\
\hline Illiterate & $4(22.2)$ & $14(77.8)$ & $18(20.0)$ & \\
\hline Educated (at least primary school) & $15(20.8)$ & $57(79.2)$ & $72(80.0)$ & \\
\hline Disease duration (month) & & & & 0.59 \\
\hline$\geq 12$ & $6(20.7)$ & $23(79.3)$ & $29(32.2)$ & \\
\hline$\leq 12$ & $13(21.3)$ & $48(78.7)$ & $61(67.8)$ & \\
\hline Marital status & & & & 0.22 \\
\hline Married & $18(23.1)$ & $60(76.9)$ & $78(86.7)$ & \\
\hline Single & $1(8.3)$ & $11(91.7)$ & $12(13.3)$ & \\
\hline Antiretroviral therapy & & & & 0.02 \\
\hline Yes & $3(5.1)$ & $56(94.9)$ & $59(65.6)$ & \\
\hline No & $16(51.6)$ & $15(48.4)$ & $31(34.4)$ & \\
\hline Neurological symptoms & & & & 0.42 \\
\hline Yes & $8(23.5)$ & $26(76.5)$ & $34(37.8)$ & \\
\hline No & $11(19.6)$ & $45(80.4)$ & $56(62.2)$ & \\
\hline $100-500$ & $3(8.6)$ & $32(91.4)$ & $35(38.8)$ & \\
\hline$>500$ & $2(5.4)$ & $11(84.6)$ & $13(14.6)$ & \\
\hline
\end{tabular}


West of Iran [12], and is lower than the corresponding values reported in Ahvaz, southwest of Iran [13], Eastern China [14], and Kuala Lumpur, Malaysia [15]. In contrast, a relatively low prevalence in HIV-infected individuals was documented elsewhere, such as $9.8 \%$ in South Africa [16]. There are several possible explanations for the low prevalence, such as greater awareness among medical teams (possibly as a result of improvements in presenting good services), prevention of contamination of foods with cat feces containing $T$. gondii oocysts, less contact with cats, climatic condition in the region, and feeding habits of eating cooked meat.

However, almost all AIDS patients with TE have detectable anti-T. gondii IgG antibodies in their serum but TE in a negative T.gondii IgG antibody test is less likely. Therefore, our finding based on Toxoplasma-IgG seroprevalence means that 21.1\% of the HIV positive patients could be at high risk to develop toxoplasmosis reactivation, and also it is as an index for development of toxoplasmosis especially when $\mathrm{CD} 4^{+} \mathrm{T}$ cell counts become under 100 cells/ $\mu \mathrm{l}$ [17]. Previous studies showed that $24-47 \%$ of T. gondii-seropositive patients ultimately developed TE [18]. In this study, clinical evidence showed that $33.3 \%$ of HIV-infected patients with positive anti-T. gondii IgG antibodies had low $\mathrm{CD}^{+}{ }^{+} \mathrm{T}$ cells rate. These patients would have a higher chance to develop TE than others who had $\mathrm{CD} 4^{+}$count $>100 \mathrm{cell} / \mu \mathrm{l}$. Also, the rate of $\mathrm{CD} 4^{+} \mathrm{T}$ cells was in a tolerable range (mean $321.0 \pm 17.3 \mathrm{cells} / \mathrm{\mu l}$ ) among our negative toxoplasmosis serology population. Therefore, the presence, as well as the titer of anti-T. gondii IgG antibodies, should be determined in all HIV patients, especially in patients with $\mathrm{CD} 4^{+}$ $<100 \mathrm{cell} / \mu \mathrm{l}$.

There was a significant association between $\mathrm{CD}^{+}$cell counts (100 cells/ $/ \mathrm{ll}$ ) and T. gondii IgG seropositivity in HIV-positive subjects; $33.3 \%$ of the HIV-positive study group, who had CD $4{ }^{+}$counts $<100$ cells/ $\mu$ l were seropositive for T. gondii $(P=0.04)$. Other studies [19] showed that $79.0 \%$ and $79.4 \%$ of these patients had $\mathrm{CD}^{+}$counts, $<100$ and $<150$ cells $/ \mu \mathrm{l}$, that are contrary to the findings in this study. Thus, $\mathrm{CD}^{+}$cell counts serve as a reliable indicator for possible toxoplasmosis, and also contribute significantly to protection against chronic T. gondii infections via their role as helper cells for antibodies production. The risk of cerebral toxoplasmosis seems to be lower in moderately severe immunodeficiency. The rate of $T$. gondii IgG seropositivity in our patients without highly active antiretroviral therapy (HAART) was high (51.6\%), that may lead to TE in HIV patients. Also, it has been mentioned that
20-47\% of all HIV positive patients with seropositive test will develop TE [20]. In our study, a lower rate of neurological symptoms was observed among HIV patients with positive serology of Toxoplasma. An interpretation on these differences might include that it is related to different levels of immunodeficiency as well as different duration of therapy. However, our patients, based on the rate of high T. gondii IgG positivity, have more risk for developing TE.

In conclusion, this study showed a low seroprevalence of latent toxoplasmosis among HIV-infected patients in Jahrom region and confirms the need for intensifying prevention efforts among this high-risk population and also the risk of toxoplasmosis reactivation which could be important among this population. There are several possible explanations for the low prevalence found in this study, as well as the reported historical differences in prevalences between regions. Taking into accounts the $78.9 \%$ patients having no prior contact with T. gondii, they must be offered health education about the transmission modes of toxoplasmosis and hygiene rules to prevent contamination. Furthermore, they have to be benefited from a regular screening of IgG anti-toxoplasmosis. We persist on the role of effective antiretroviral therapy and the primary prevention measurements to avoid the evolution toward toxoplasmosis in this region.

\section{ACKNOWLEDGMENT}

This work was extracted from medical student thesis and was financially supported by Zoonotic Diseases Research Center in Jahrom University of Medical Sciences, Jahrom, Iran.

\section{CONFLICT OF INTEREST}

We have no conflict of interest related to this work.

\section{REFERENCES}

1. Grant IH, Gold JW, Rosenblum M, Niedzwiecki D, Armstrong D. Toxoplasma gondii serology in HIV-infected patients: the development of central nervous system toxoplasmosis in AIDS. AIDS 1990; 4: 519-522.

2. Mamidi A, DeSimone JA, Pomerantz RJ. Central nervous system infections in individuals with HIV-1 infection. J Neurovirol 2002; 8: 158-167.

3. Machala L, Malý M, Hrdá S, Rozsypal H, Stanková M, Kodym P. Antibody response of HIV-infected patients to latent, cerebral 
and recently acquired toxoplasmosis. Eur J Clin Microbiol Infect Dis 2009; 28: 179-182.

4. Daryani A, Sarvi S, Aarabi M, Mizani A, Ahmadpour E, Shokri A, Rahimi MT, Sharif M. Seroprevalence of Toxoplasma gondii in the Iranian general population: a systematic review and meta-analysis. Acta Trop 2014; 137: 185-194.

5. Jones JL, Ogunmodede F, Scheftel J, Kirkland E, Lopez A, Schulkin J, Lynfield R. Toxoplasmosis-related knowledge and practices among pregnant women in the United States. Infect Dis Obstet Gynecol 2003; 11: 139-145.

6. Ruiz-Fons F, Vicente J, Vidal D, Höfle U, Villanúa D, Gauss C, Segalés J, Almería S, Montoro V, Gortázar C. Seroprevalence of six reproductive pathogens in European wild boar (Sus scrofa) from Spain: the effect on wild boar female reproductive performance. Theriogenology 2006; 65: 731-743.

7. Song KJ, Shin JC, Shin HJ, Nam HW. Seroprevalence of toxoplasmosis in Korean pregnant women. Korean J Parasitol 2005; 43: 69-71.

8. Hari KR, Modi MR, Mochan AH, Modi G. Reduced risk of Toxoplasma encephalitis in HIV-infected patients-a prospective study from Gauteng, South Africa. Int J STD AIDS 2007; 18: 555-558.

9. Fan CK, Hung CC, Su KE, Chiou HY, Gil V, Ferreira Mda C, Tseng LF. Seroprevalence of Toxoplasma gondii infection among inhabitants in the Democratic Republic of São Tome and Principe. Trans R Soc Trop Med Hyg 2007; 101: 1157-1158.

10. Jones CD, Okhravi N, Adamson P, Tasker S, Lightman S. Comparison of PCR detection methods for B1, P30, and 18S rDNA genes of $T$. gondii in aqueous humor. Invest Ophthalmol Vis Sci 2000; 41: 634-644.

11. Davarpanah M, Mehrabani D, Neirami R, Ghahremanpoori M, Darvishi M. Toxoplasmosis in HIV/AIDS patients in Shiraz, southern Iran. Iran Red Crescent Med J 2007; 9: 22-27.
12. Rostami A, Keshavarz H, Shojaee S, Mohebali M, Meamar AR. Frequency of Toxoplasma gondii in HIV positive patients from West of Iran by ELISA and PCR. Iran J Parasitol 2014; 9: 474481.

13. Alavi SM, Jamshidian R, Salmanzadeh S. Comparative study on Toxoplasma serology among HIV positive and HIV negative illicit drug users in Ahvaz, Iran. Caspian J Intern Med 2013; 4: 781784.

14. Shen G, Wang X, Sun H, Gao Y. Seroprevalence of Toxoplasma gondii infection among HIV/AIDS patients in Eastern China. Korean J Parasitol 2016; 54: 93-96.

15. Nissapatorn V, Lee C, Quek KF, Leong CL, Mahmud R, Abdullah KA. Toxoplasmosis in HIV/AIDS patients: a current situation. Jpn J Infect Dis 2004; 57: 160-165.

16. Kistiah K, Winiecka-Krusnell J, Barragan A, Karstaedt A, Frean J. Seroprevalence of Toxoplasma gondii infection in HIV-positive and HIV-negative subjects in Gauteng, South Africa. South Afr J Epidemiol Infect 2011; 26: 225-228.

17. Lindström Kaddu-Mulindwa DH, Kironde F, Lindh J. Prevalence of latent and reactivated Toxoplasma gondii parasites in HIV-patients from Uganda. Acta Trop 2006; 100: 218-222.

18. Zangerle R Allerberger F, Pohl P, Fritsch P, Dierich MP. High risk of developing toxoplasmic encephalitis in AIDS patients seropositive to Toxoplasma gondii. Med Microbiol Immunol 1991; 180: 59-66.

19. Osunkalu VO, Akanmu SA, Ofomah NJ, Onyiaorah IV, Adediran AA, Akinde RO, Onwuezobe IA. Seroprevalence of Toxoplasma gondii IgG antibody in HIV-infected patients at the Lagos University Teaching Hospital. HIV/AIDS 2011; 3: 101-105.

20. Bennett JE, Dolin R, Blaser MJ. Principles and Practice of Infectious Diseases, 8th ed. Philadelphia, Pennsylvania, USA. Elsevier Saunders. 2014, pp 310-315. 